\title{
PERAN FAKTOR INTERNAL DAN FAKTOR EKSTERNAL PADA KEBERLANGSUNGAN START-UP BISNIS KOTA SURABAYA
}

\author{
Fransisca Desiana Pranata Sari ${ }^{1}$ \\ Sri Nathasya Br Sitepu² \\ Program Studi Manejemen, Fakultas Manajemen dan Bisnis, Universitas Ciputra Surabaya \\ Email : fransisca.desiana@ciputra.ac.id' dan nathasya.sitepu@ciputra.ac.id²
}

\begin{abstract}
Business Competition encourages entrepreneurs to have competence in managing the business. Start-up businesses will grow if it is able to manage the internal factors and external factors well. This study focuses on internal factors from the perspective of companies consisting of four components, namely marketing, human resources, finance, and operations. The second focus of this study is the external factor of a business seen from the approach five forces Porter lists five essential components of the external factors, namely: barriers to entry in the industry, threat from substitute products, threat from suppliers bargaining power, threat from buyers bargaining power, Among existing industry and rival firms. The object of this study is a start-up business in the city of Surabaya. This study used descriptive qualitative method with the aim of optimizing the management view of internal and external factors in the success of a start-up business seen from the perspective of the company. Validation of the results using triangulation techniques using: parisipatif observation, interview, and documentation (photos and interviews) to the informant (object) research. The results showed the management of internal factors (marketing, human resources, finance, and operational) and external (barriers to entry in the industry, threat from substitute products, threat from suppliers bargaining power, threat from buyers bargaining power, and rival Among existing industry firms ) is an important component that must be optimized in order to support the success of start-up businesses.
\end{abstract}

Keywords: Business Startup, Internal factors, External factors,

\section{LATAR BELAKANG}

Badan Pusat Statistik (BPS) menyediakan Data Produk Domestik Bruto atas Dasar Harga Konstan (PDB) wilayah Jawa Timur menunjukkan peningkatan mulai dari tahun 2000 hingga tahun 2013. Pada Tahun 2013 besarnya sumbangsih sektor industry terhadap prekonomian Jawa Timur sebesar Rp. 98.017.056.000.000. Sektor industry tersebut dapat dibagi lagi menjadi sembilan sub sektor diantaranya: industry makanan, minuman dan tembakau, tekstil pakaian jadi dan kulit, idustri kayu dan sejenisnya, kertas percetakan dan penerbitan, kimia, minyak bumu, karet dan plastic, barang galian non logam, idustri logam dasar, idustri barang dari logam mesin dan peralatan, dan terakhir industry pengolahan lainnya. Pendapatan tersebut menjadi buti yang kuat bahwa sektor industri memiliki pertumbuhan yang pesat di Jawa Timur.

Perkembangan industri di wilayah Jawa Timur tidak terlepas dari adanya perkembangan industry di daerah Kota Surabaya. Badan Pusat Statistik mencatat Produk Domestik Bruto Kota Surabaya dari sektor industri mulai tahun 2000 hingga 2012 mengalami peningkatan namun pada tahun 2013 mengalami penurunan dari tahun sebelumnya. Besarnya sumbangan sektor industry pada tahun 2012 mencapai angka 21, 07\% namun pada tahun 2013 mengalami penurunan menjadi 20,52\%. Hal ini menjadi temuan yang sangat menarik dimana pada saat sumbangan sektor industry di wilayah Jawa timur mengalami peningkatan setiap tahunnya namun perkembangan sektor industry kota Surabaya justru mengalami penurunan. 
Berbicara mengenai sektor industry sangat berhubungan dengan sebuah bisnis. Bisnis sendiri memiliki beberapa kriteria yaitu: bisnis/ usaha skala kecil biasanya disebut start-up bisnis, bisnis skala menengah dan terakhir adalah bisnis yang besar(sustainable business). Pada sebuah bisnis kita akan dapat melihat dari dua sudut padang yang berbeda yaitu: sudut pandang bisnis (secara organisasi) dan aspek diluar bisnis yang mempengaruhi bisnis. Aspek bisnis dari sudut pandang organisasi sudah pasti merupakan faktor internal sebuah perusahaan/bisnis. Aspek internal sebuah bisnis dapat dilihat dari pemilik/ entrepreneur dan organisasi (aspek manajemen). Pengelolaan aspek manajemen harus dilakukan dengan teliti dan optimal sehingga dapat mempercepat pertumbuhan bisnis yang sedang dijalankan..Aspek eksternal sebuah bisnis merupakan aspek yang berada di luar sebuah bisnis namun mampu memberikan pengaruh terhadap keberlangsungan bisnis.Sebagai contoh pelanggan merupakan aspek yang berada di luar sebuah perusahaan namun, besarnya loyalitas pelanggan dalam mengkonsumsi produk yang dihasilkan oleh sebuah perusahaan akan mempengaruhi besarnya pendapatan sebuah perusahaan.

Perusahaan yang gagal dalam mengelola aspek internal dan eksternal dari bisnisnya akan terancam mengalami kebangkrutan sehingga tidak dapat bersaing dengan perusahaan/bisnis lainnya yang ada dipasar. Pengelolaan perusahaan/ bisnis sangat penting sekali dilakukan oleh start-up bisnis.Peluang kegagalan dalam pengelolaan start-up bisnis lebih besar dibandingkan dengan perusahaan yang berskala menegah atau besar.Hal ini dikarenakan pada level start-up bisnis sebuah bisnis harus memiliki optimalisasi pada pengelolaan faktor internal.Start-up bisnis harus mampu mempertahankan produk/jasa yang dihasilkan tetap diterima oleh pasar walaupun harus menghadapi persaingan dipasar.

Start-up bisnis harus mampu melewati masa-masa kritis sebuah usaha yang biasanya sangat rentan pada bisnis usia 1-5 tahun. Dalam kurun waktu kritis dilima tahun pertama start-up bisnis harus mampu menyeimbangkan anatara pengelolaan faktor internal sekaligus dalam saat bersamaan juga mengelola faktor eksternal.Startegi bisnis harus tepat pada sasaran sehingga mencapai hasil yang optimal/berpengaruh positip bagi keberlangsungan sebuah start-up bisnis.

Pentingnya pengelolaan faktor internal dan faktor eksternal pada sebuah start-up bisnis di Kota Surabaya merupakan hal yang harus dicari solusinya sehingga seluruh start-up bisnis Kota Surabaya mengalami pertumbuhan yang pada akhirnya akan memberkan pengaruh postip untuk dapat meningkatkan jumlah PDRB Kota Surbaya khususnya dari sektor industri kecil dan menengah.Konsentrasi pada sektor usaha kecil dikarenakan dari semua sektor industry jumlah dari sektor usaha kecil lebih banyak sehingga start-up bisnis merupakan sektor yang sangat berpengaruh terhadap kemajuan bisnis Kota Surabaya. Berdasarkan dari uraian kondisi sektor perindustriaan di Wilayah Jawa Timur khususnya Kota Surabaya maka diperlukan penelitian terkait start-up bisnis dengan judul ;PERAN FAKTOR INTERNAL DAN FAKTOR EKSTERNAL PADA KEBERLANGSUNGAN START-UP BISNIS KOTA SURABAYA.

Penelitian ini akan melakukan kajian mendalam untuk dapat mencapai keberlangsungan start-up bisnis maka penelitian ini akan mencari solusi dari pertanyaan penelitian diantaranya sebagai berikut:

1. Bagaimana peran faktor internal pada keberlangsungan start-up business?

2. Bagaimana peran faktor eksternal pada keberlangsungan start-up business?

\section{TINJAUAN PUSTAKA}

\section{Start-Up Business}

Start up business merupakan perusahaan rintisan yang umurnya kurang dari lima tahun dengan tahapan pertumbuhan untuk mencapai tujuan menuju kesuksesan sesuai yang perusahaan tentukan secara internal (Sutanto 2008). 
" a term used for a young business, most often applied when the business has the intent of potential to grow to substantial size" (Abrams 2012: 3).

Sifat perusahaan/bisnis dalam tahapan pertama ini masih tergolong dinamis dan fokus pada permintaan pasar serta pemenuhannya (Sutanto 2008). Awal berdirinya perusahaan ini biasanya sangat rentan terhadap resiko kebangkrutan/gulung tikar karena perusahaan tidak memperhitungkan secara detail bagaimana perusahaan tersebut akan dikembangkan melihat dari sisi internal maupun eksternal perusahaan. Menurut Echdar (2013: 62), kegagalan start-upbusiness umumnya disebabkan oleh sikap pendirinya/pemiliknya yang kurang berkomitmen untuk mencapai keberhasilan perusahaan baik saat krisis maupun saat sukses, disamping itu perusahaan juga mengalami kurangnya perencaan dan pengelolaan keuangan yang baik, pemilihan lokasi yang kurang tepat, pengendalian bisnis yang tidak konsisten, manejemen yang tidak jelas dan tidak tegas.

Menurut Blackburn (2013), strategi bisnis dirasakan sangat penting bagi keberlanjutan sebuah bisnis, dimana strategi perusahaan pada dasarnya digunakan untuk mengatasi tuntutan perubahan dari lingkungan eksternal dan lingkungan internal. Hal ini akan sering kali dialami perusahaan dalam keseluruhan fase pertumbuhannya. Dengan demikian, perusahaan perlu mengatur stategi pengelolaan yang baik bagi perusahaannya.

Perusahaan harus mempu mengatasi kemungkinan buruk yang terjadi pada perusahaan untuk mencapai keunggulan kometitif perusahaannya. Keunggulan kompetitif adalah suatu keadaan dimana perusahaan mampu mencapai kesuksesan dan bersaing dengan perusahaan atau kompetitornya (Clancy dan Egeraat 1999). Perusahaan perlu melakukan identifikasi/observasi awal terhadap faktor-faktor yang berperan dalam keberhasilan start up business untuk mempertahankan perusahaannya. Peran yang dimaksud adalah dari faktor internal dan faktor eksternal. Kedua faktor ini sebaiknya perlu menjadi fokus utama perusahaan dalam mengembangkan bisnisnya supaya dapat bertahan dalam persaingan.

Menurut Wood (2006), performance perusahaan dapat dilihat dari dua faktor penting yaitu economic business performance dan organizational business performance.Economic business performance ini menjelaskan eksternal organisasi yang memungkinkan perusahaan mendapat dukungan atau hambatan dalam bertumbuh. Organizational business performance ini menjelaskan internal organisasi perusahaan yang mencerminkan perilaku perusahaan dan lingkungan perusahaan.

\section{Faktor Internal}

Menurut Blackburn (2013), atribut yang berperan dalam kemajuan dan pertumbuhan sebuah perusahaan adalah entreprneur, strategi, dan perusahaan. Dengan demikian perlu ada kolaborasi dari ketiga pihak tersebut untuk mengembangkan perusahaan menuju keunggulan kompetitif. Menurut Wood (2006), variabel yang mewakili faktor internal perusahaan adalah karakteristik organisasi, pengukuran kinerja, aktivitas pemasaran, pegawai dan training, kualitas manajemen, dan outsourcing serta keuangan.

Perusahaan perlu mengenali dulu bagaimana sistem intern perusahaan dijalankan dan bagaimana hal tersebut dapat dipakai untuk mencapai tujuan perusahaan. Secara umum, Echdar (2013: 86) mengelompokkan faktor internal ke dalam dua persfektif yaitu perspektif individu dan perspektif perusahaan (bisnis). Faktor internal dari persfektif perusahaan terdiri dari empat kemampuan utama yaitumarketing, human resource, finance, dan operational (Echdar, 2013: 86).

Kompetensi teknis dilakukan sebuah organisasi bisnis terkait dengan rancangan usaha sampai kepada sistem yang digunakan. Kompetensi pemasaran diperlukan dalam rangka menemukan pasar yang tepat sehingga fokus kepada kebutuhan pelanggan dan demi 
menjaga kelangsungan hidup perusahaan. Pengelolaan aspek keuangan merupakan kompetensi yang penting pula karena perusahaan perlu mengatur seluruh keuangannya dengan baok terkait dengan pembelian, penjualan, pemukuan, sampai laporan keuangan untuk memberikan informasi mengenai kondisi perusahaan setiap bulannya. Pengelolaan yang terkait hubungan manusia dimana perusahaan perlu mengembangkan hubungan personal, berelasi dan membangun sebuah jaringan.

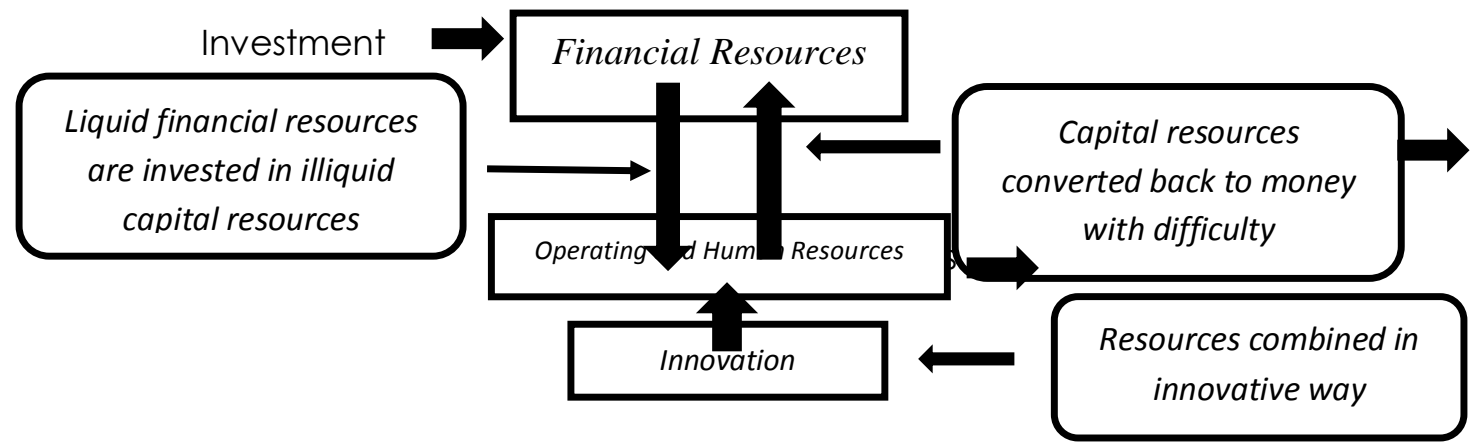

Gambar 2.1. Resource commitment in the entrepreneurial venture (Wichmam 2004)

\section{Faktor Eksternal}

Sejak tahun 1979, banyak perusahaan yang sudah menggunakan porter's five forces untuk melihat keunggulan kompetitifnya dibandingkan dengan kompetitor jika dilihat tidak dari aspek internal perusahaan namun secara faktor eksternal perusahaan (Wang dan Chang 2009). Menurut Sutanto (2008), perusahaan harus mampu melakukan sikap adptif terhadap persaingan global, terutama persaingan dari sisi eksternal perusahaan yang dapat menjadi ancaman bagi seluruh sumber daya perusahaan. Lima kekuatan yang dilihat dari faktor eksternal perusahaan ini terdiri dari: kondisi industry kompetitor, potensi masuk ke pasar yang sama dengan perusahaan, suplier, buyers, dan produk substitusi (Wang dan Chang 2009). Porter's five forcesini menjadi strategi dasar perusahaan yang dipercaya dapat meningkatkan keunggulan kompetitif perusahaan sehingga return yang didapatkan perusahaan juga meningkat (Akan et al. 2006). Pembangunan terhadap sebuah keunggulan kompetitif harus memahami kondisi marketing yang terjadi di pasar, seperti bagaimana situasi pasar dengan produk substitusi, hambatan masuk pasar yang sama, kekuatan posisi perusahaan, kompetensi inti perusahaan, inovatif, dan dasar kompetisi (Clancy dan Egeraat 1999). Determinasi dan kluster keunggulan kompetitif tergambarkan dalam gambar 2.1 sebagai berikut:

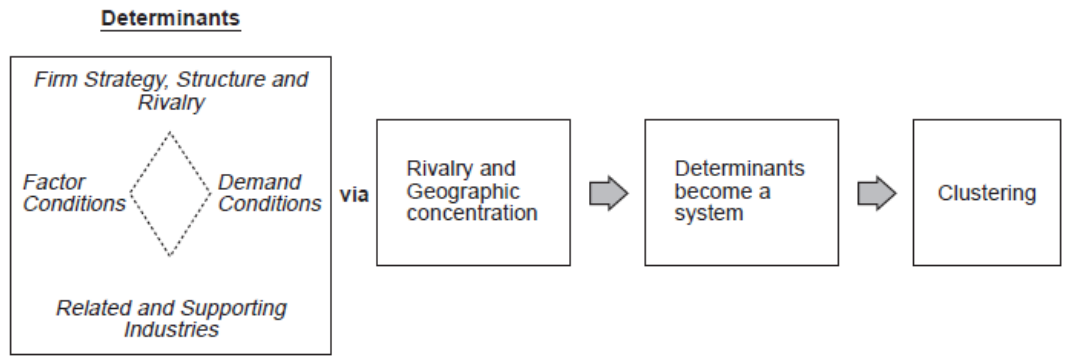

\section{Gambar 2.2. Determinasi dan kluster keunggulan kompetitif (Clancy dan Egeraat,1999)}

Hal ini sejalan dengan pendapat Allen (1999) bahwa faktor eksternal yang perlu disadar perusahaan agar mampu bersaing dengan pasar dan komptetitor adalah barriers to entry in the industry, threat from substitute products, threat from suppliers bargaining power, threat 
from buyers bargaining power, dan rival among existing industry firms.Barriers to entry in the industry merupakan situasi dimana perusahaan perlu memahami bagaimana hambatan yang mungkin dihadapi untuk masuk ke pasar yang sama dengan perusahaan. Hal ini perlu disadari sejak awal agar perusahaan siap menghadapi persaingan pasar. Threat from substitute products merupakan situasi dimana perusahaan perlu memahami apakah terdapat produk yang mampu menggantikan fungsi produk yang dihasilkan perusahaan. Apabila terdapat hal ini maka akan dapat mengurangi market share perusahaan. Hal ini perlu diwaspadai supaya perusahaan siap dengan segala kemungkinan yang terjadi. Threat from suppliers bargaining power merupakan situasi dimana perusahaan perlu mengetahui posisinya dimata suplier. Apabila suplier posisinya lebih kuat daripada perusahaan, maka perusahaan perlu waspada dan berusaha mencari solusi untuk mengurangi kekuatan suplier terhadap perusahaan.Salah satu solusi yang menjadi alternative adalah dengan segera mencari supplier baru yang memiliki kemampuan yang sama dengan supplier yang saat ini sedang memasok barang. Threat from buyers bargaining powermerupakan situasi dimana perusahaan perlu menyadari posisi konsumen terhadap perusahaan. Situasi ini berkaitan dengan kemudahan konsumen berpindah ke produk lain menunjukan kekuatannya ke perusahaan.Rival among existing industry firms merupakan situasi dimana perusahaan perlu membaca kondisi persaingan saat ini dan bagaimana posisi kompetitor terhadap perusahaannya.

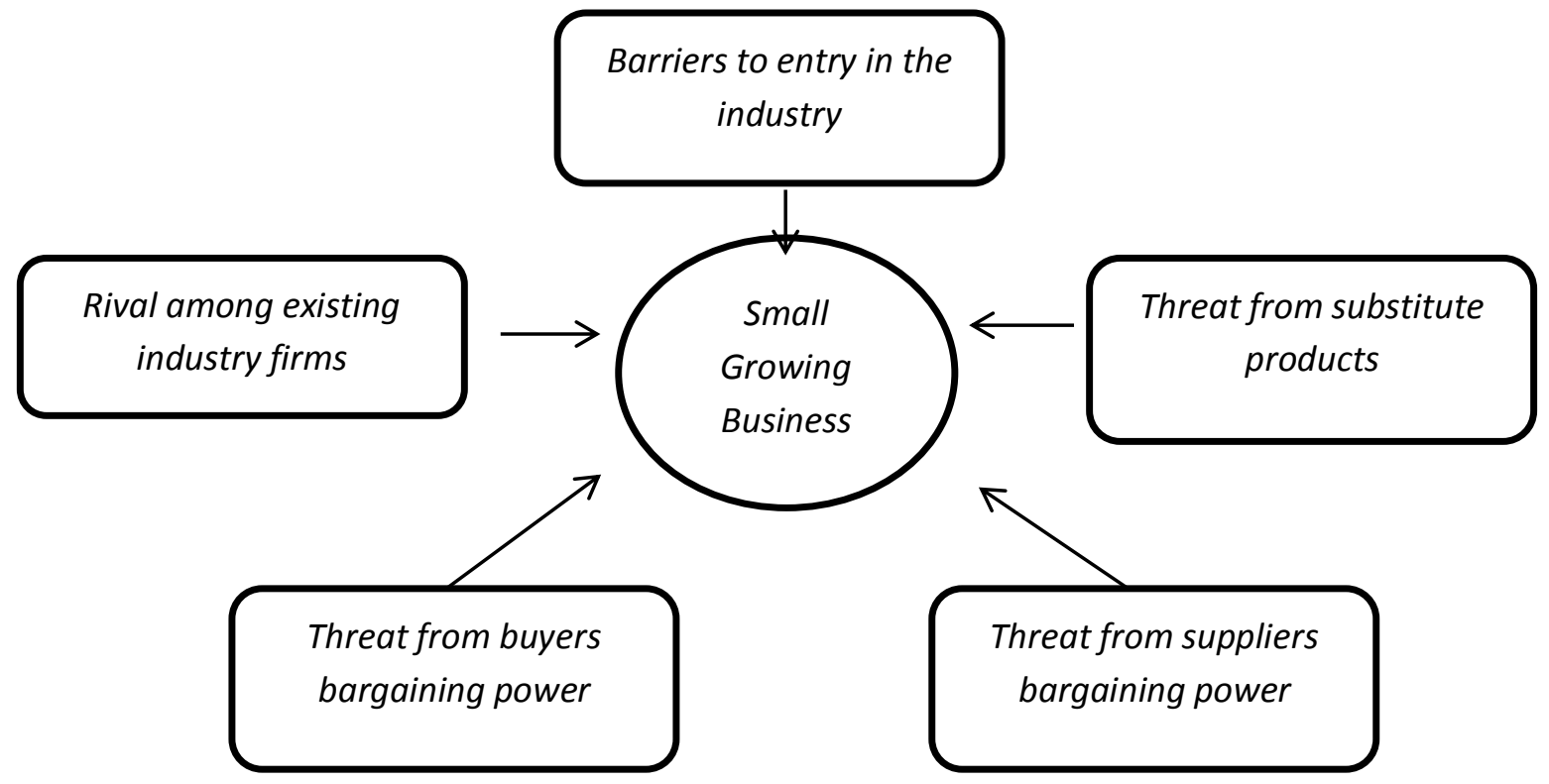

Gambar 2.3. Forces Affecting Small Business (Allen 1999)

Menurut Wang dan Chang (2009), beberapa negara dapat sukses dalam berbisnis seperti China karena mereka fokus membaca tren kolaborasi kompetisi pasar. Alternatif kolaborasi kompetisi pasar yang menjadi fokus China adalah dimulai dari business purpose, business climate, business location, business organization, dan business leader.

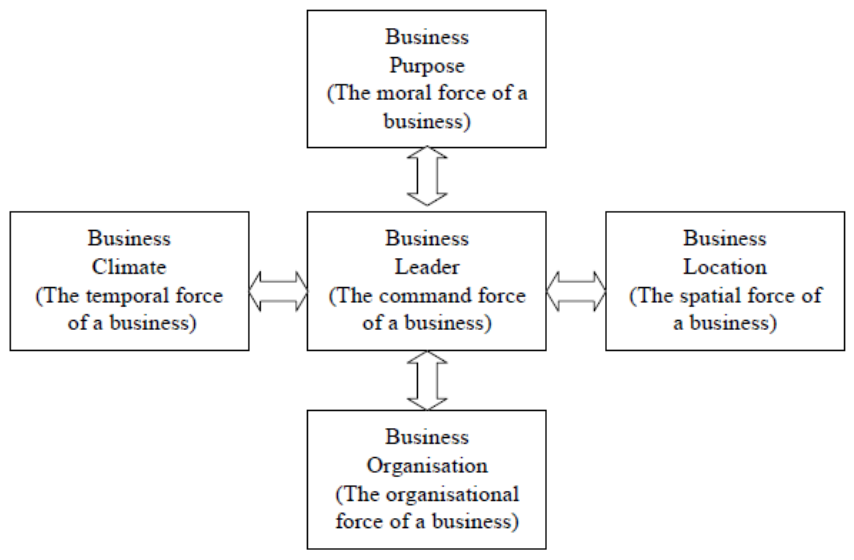




\section{Gambar 2.4. Kolaborasi lima kekuatan sukses dalam bisnis (Wang dan Chang 2009)}

\section{METODE PENELITIAN}

Penelitian ini merupakan penelitian yang dijabarkan secara deskriptif kualitatif, yaitu akan dijabarkan dalam bentuk analisa deskriptif untuk mengeksplorasi lebih dalam mengenai topik mempertahankan keberlangsungan sebuah start up business.Tahapan kegiatan yang dilakukan dalam penelitian kualitatif secara umum, yaitu di awali dengan menentukan research problem, kemudian mencariliterature review, sampai membuat metode yang cocok digunakan dalam mengumpulkan data, memastika data terkumpul dengan baik, menganalisis data, dan memberikan kesimpulan (Chairiri 2009). Menurut Cooper (2006: 226), penelitian kualitatif ini biasanya berbentuk narasi atas sebuah kejadian sosial dalam bermasyarakat secara alami. Penelitian kualitatif menggunakan teori sebagai dasar dan alat dalam penelitian untuk menemukan masalah kemudian melakukan pengamatan sampai dengan menguji data (Bungin, 2013: 24).

Menurut Chairiri (2009) tujuan utama pendekatan penelitian dilakukan dengan pendekatan kualitatif adalah untuk membuat fakta yang mudah dipahami atas sebuah fenomena baru yang dalam kasus tertentu dapat memungkunkan menghasilkan sebuah model bahkan hipotesis baru untuk penelitian lanjutan atas kasus yang sama. Penelitian kali ini menggunakan model existential phenomenologyyaitu peneliti berusaha untuk memahami esensi pengalaman seseorang atas kasus tertentu dengan cara mengelompokkan isu yang ada atas pengalaman mereka kemudian memberikan makna atas isu tersebut sesuai pandangan orang tersebut (Chairiri 2009). Teknik pengum[ulan data untuk model Existential Phenomenology ini yang cocok menggunakan metode videotype, interview, interpretasi, ethnography, observasi. (Chairiri 2009). Berdasarkan saran Chairiri (2009) tersebut, teknik pengumpulan data yang cocok dalam penelitian ini adalah interview, interpretasi, dan observasi. Pada proses interview, peneliti mencatat keseluruhan opini, perasaan, emosi, dan lainnya yang berkaitan dengan individu dalam organisasi (Chairiri 2009).

Subjek penelitian ini adalah orang yang merupakan pelaku start up business yang berada di Surabaya. Teknik pemilihan subjek penelitian dilakukan dengan teknik purposive sampling.Menurut Sugiyono (2013: 392), teknik purposive sampling yaitu teknik pemilihan subjek penelitian yang dilakukan berdasarkan penentuan pertimbangan tertentu dalam rangka mendapatkan data terkait tujuan penelitian. Kriteria narasumber tersebut adalah lokasi bisnis di Kota Surabaya, umur bisnis kurang lebih 2 tahun, memiliki sistem baik dan terstruktur. Objek penelitian dalam penelitian ini adalah peran faktor internal dan eksternal pada keberlangsungan start up business kota surabaya. Data primer didapatkan dari hasil wawancara dan observasi yang dilakukan kepeada narasumber. Data sekunder didapatkan dari beberapa literartur tambahan dan data yang dipublikasikan oleh negara (Data BPS). Data dari responden penelitian dijelaskan pada tabel dibawah ini.

Tabel 3.1. Profil Narasumber

\begin{tabular}{|l|l|l|l|l|}
\hline No & \multicolumn{1}{|c|}{ Nama } & Nama Bisnis & \multicolumn{1}{|c|}{ Identitas Bisnis } & \multicolumn{1}{c|}{ Jenis Produk } \\
\hline 1 & $\begin{array}{l}\text { Lisa } \\
\text { Boediono }\end{array}$ & $\begin{array}{l}\text { Tokonyalisa. } \\
\text { com }\end{array}$ & $\begin{array}{l}\text { Berdiri selama 4 } \\
\text { tahun di Kota } \\
\text { Surabaya }\end{array}$ & $\begin{array}{l}\text { Makanan dan bumbu impor yang } \\
\text { penjualannya berkembang dengan } \\
\text { menggunakan media sosial sebagai } \\
\text { sarana promosi. }\end{array}$ \\
\hline 2 & Wiliam & Kampung & 2 tahun Beroprasi & Kopi siap seduh yang menawarkan \\
\hline
\end{tabular}




\begin{tabular}{|l|l|l|l|l|}
\hline & Alfredo & $\begin{array}{l}\text { Arab } \\
\text { Indonesia }\end{array}$ & di Kota Surabaya & $\begin{array}{l}\text { value kopi yang digabungkan } \\
\text { dengan khasiat rempah-rempah asia } \\
\text { tenggara. }\end{array}$ \\
\hline 3 & Chesya & $\begin{array}{l}\text { Baite and } \\
\text { Bite }\end{array}$ & $\begin{array}{l}2 \text { tahun dan } \\
\text { berada di Kota } \\
\text { Surabaya }\end{array}$ & $\begin{array}{l}\text { Cookies kalengan rasa Greentea dan } \\
\text { Coklat yang menawarkan value } \\
\text { kesehatan bagi para konsumen } \\
\text { karena menggunakan bahan baku } \\
\text { oatmeal. }\end{array}$ \\
\hline 4 & $\begin{array}{l}\text { Chandra } \\
\text { Triana }\end{array}$ & $\begin{array}{l}\text { Sambal } \\
\text { Kobonk }\end{array}$ & $\begin{array}{l}\text { Oprasional } \\
\text { selama 2 tahun di } \\
\text { Kota Surabaya. }\end{array}$ & $\begin{array}{l}\text { Sambal dalam kemasan dan warung } \\
\text { nasi dengan sambal berbagai level } \\
\text { di Surabaya Barat. Sambal yang } \\
\text { ditawarkan tanpa bahan pengawet } \\
\text { sehingga tidak memberikan } \\
\text { pengaruh negative pada kesehatan. }\end{array}$ \\
\hline 5 & Mega & Mega Food & $\begin{array}{l}\text { Bisnsi mulai } \\
\text { operasional } \\
\text { selama 1 tahun di } \\
\text { Kediri dan Kota } \\
\text { Surabaya }\end{array}$ & $\begin{array}{l}\text { Sambal daging dalam kemasan } \\
\text { yang diolah secara higenis dan } \\
\text { menggunakan bahan pilihan yang } \\
\text { berkualitas. }\end{array}$ \\
\hline
\end{tabular}

Sumber: Data Primer, 2016

Keabsahan data perlu digunakan dalam penelitian yaang dilakukan secara kualitatif. Keabsahan data ini penting untuk memastikan adanya hasil yang objektif dalam interpretasi data. Penelitian ini menggunakan triangulasi sumber sebagai bentuk keabsahan data. Triangulasi sumber ini dilakukan dengan membandingkan jawaban narasumber yang relevan dengan penelitian kali ini.

\section{HASIL DAN PEMBAHASAN}

\section{Analisis Peran Faktor Internal Pada Keberlangsungan Start-Up Business}

Faktor internal dalam sebuah start-up bisnis pasti memiliki aspek Technical competence dimana responden Toko Lisanya berpendapat bahwa aspek Technical competencetidak perlu terlalu rumit diakrenakan tingkat urgensi aspek ini sangat kecil lebih penting menitik beratkan pada aspek marketing. Respon penelitian kedua menanggapi bahawa aspek Technical competence harus dijalankan hal ini dibuktikan dengan penggunaan S.O.P yang disusun dalam flowcharts yang sudah diterpakan pada realisasi dialur produksi, pembelian, keuangan, sumberdaya manusia dan pemasaran.Ketika Kopi kampoeng Arab merealisasikannya meraka mendapatkan mafaat dibuktikan melaluibenefit yangdiperoleh yaitu: berhasil mengantongi izin legalitas (PIRT), menang dalam kompetisi bisnis dengan memenuhi technical competence. Responden ketiga yaitu Sambel kobonk yang telah menerapkan sistem produksi,operasional dan sistem keuangan. Bentuk nyata dari penerapan technical competence masih sering mengalami kegagalan/ masalah terutama pada sistem sumber daya manusia dimana, tenaga kerja kurang professional. Responden keempat Baite and Bite sudah memiliki technical competence yang terlihat pada alur produksi namun masih saja menemui kendala hal ini dipicu oleh realisasi kurang maksimal sesuai degan alur. Responden kelima mengatakan bahwa technical competence dalam bisnisnya masih sangat rendah.Keterbatasan jumlah tenaga kerja dan usia bisnis serta modal yang rendah menjadi penyebab mengapa Mega Food belum mampu menerapkan aspek technical competence pada bisnis yang dijalankan

Aspek kedua pada faktor internal yaitu aspek marketing yang dimiliki oleh kelima entrepreneur yang menjadi responden dalam penelitian. Toko Lisanya menjalankan aspek 


\section{Fransisca Desiana Pranata Sari Sri Nathasya Br Sitepu}

marketing dengan sesuai dengan target yang sudah ditetapkan secara jelas dan rinci. Toko Lisanya menggunakan sosial media karena mayoritas konsumennya adalah pengguna sosial media.Responden Mega Food menjalankan aspek marketing melalui promosi yang manual hanya mengandalkan kekatan promosi individu dari mulut ke mulut.Sehingga biaya marketing relative rendah namun progress penjualan juga bergerak dengan lambat.Reponden Kobonk menjankan usaha dengan system marketing business to business (B2B).Sistem marketing yang dijalankan Kobonk melalui keikutsertaan pameran untuk menggandeng reseller.Selain itu banyak juga pelanggan dari Kobonk berubah fungsi menjadi reseller hanya karena sebagian komunitas pelanggan juga mencintai dan menggemari produk mereka. Kopi Kampoeng Arab memilih target pasar yang menjadi sasaran dari aspek marketing adalah masyarakat yang mencintai kopi dan budaya Timur Tengah. Teknik marketing yang digunkan adalah B2B dimana bisnis ini sangat aktif masuk melalui komunitas masyarakat Timur Tengah dan sekaligus mempromosikan produk kopi mereka di acara yang diikuti.

Faktor internal pada aspek ketiga adalah aspek financial competencepada Toko Lisanya sangat mandiri dalam aspek financial competencehal ini dibuktikan dengan kepemilikan modal yang bersumber dari entrepreneur sendiri (tanpa ada modal tambahan dari pemilik usaha lainnya). Sistem pencataatan keuangan juga dikerjakan dengan system manual hal ini karena entrepreneur merasa transaksi yang ada dalam toko masih mampu ditangani sendiri tanpa bantuan software. Mega Food mendapatkan modal bukan dari kemampuan ekonomi pemilik bisnis/entrepreneur melainkan berasal dari dukungan modal dari pihak eksternal(orangtua entrepreneur). Kondisi keuangna perusahaan baru mencapai titik impas diamana semua pencatatan keuangan dilakukan secara manual.Prinsip keuangan Mega Food hanya berorentasi pada kemampuan keuangan untuk membiayai seluruh kegiatan operasional start-up bisnis Start-up bisnis yang dijalankan oleh Kobonk memiliki financial competence yang relative baik karena dukungan modal untuk menjalankan bisnis berasal dari para pemilik usaha (tiga orang entrepreneur).Seluruh aktivitas keuangan Kobonk dicatat dalam jurnal dan transaksi harian di catat dalam pencatatan kevangan harian.Kopi Kampoeng Arab memiliki modal atau financial competence yang kuat karena bisnis ini memiliki 5 orang entrepreneur yang menjalankan dan menopang usaha ini artinya bisnis ini tidak mengalami kesulitan dalam memperoleh modal.Sumber pendanaan juga diperoleh dari hadiah dari sejumlah kompetisi yang diikuti oleh entrepreneur pemilik bisnis dan sumber pendanaan lainnya adalah dana hibah dari instansi pemerintah yang diterima. Bisnis kopi Kampoeng Arab sudah mampu membagikan sisa hasil usaha rutin setiap bulannya kepada seluruh pemilik bisnis.Seluruh pencatatan keuangan dilakukan secara rutin setiap hari.Financial competence yang dimiliki oleh responden dari bisnis Baite and Bite memperoleh modal awal dari para pemilik bisnis yang berjumlah empat orang. Semua pencatatan transaksi yang ada pada bisnis Baite and Bite menggunakan bantuan software accuret sehingga kondisi keuangan dapat up-date dengan dilengkapi tingkat aruasi tinggi.

Human relation adalah aspek yang penting dalam faktor internal dalam sebuah start-up bisnis.Toko Lisanya dikelola oleh seorang entrepreneur.Toko lisanya juga memiliki aspek human relation dapat dilihat dari hubungan entrepreneur dengan supplier dan konsumen tergambarkan dari bagaimana keahlian entrepreneur untuk membuat supplier serta konsumen agar tetap loyal memberikan pengaruh positip terhadap keberhasilan bisnis di Toko Lisanya. Mega food memiliki aspek human relation dalam menjalin hubungan antara entrepreneur pemilik start-up bisnis dengan tenaga kerja yang membantu operasional bisnis. Teknik pendelegasian tugas dan apresiasi terhadap kinerja karyawan merupakan bukti mega food dalam menjalankan aspek human relation. Mega Food juga senantiasa berupaya untuk menjalin hubungan dan komunikasi yang beiak dengan pelanggan dan pemasok bahan baku. Kobonk memiliki human relation pada aspek internal perusahaan. Aspek human relation pada Kobonk dibagi empat dimensi yaitu: human relation antara pemilik usaha, human relation antara entrepreneur Kobonk dengan karyawan yang sering kali mengalami salah paham ketika mencoba mengerti makna dibalik komunikasi 
disebabkan karena keterbatasan kemampuan karyawan yang dipekerjakan sehingga S.O.P. harus terus menerus diingatkan untuk dijalankan karyawan. Human relation dapat diperbaiki Kobonk melalui evaluasi mingguan dimana seluruh karyawan akan menerima refresh terkait S.O.P. sehingga dapat dijalankan dengan lebih baik dan sesuai ketentuan oleh semua karyawan. Start-up bisnis Kopi Kampoeng Arab menjalankan aspek human relationdengan cara melakukan komunikasi/ rapat mingguan dengan anggota pemilik bisnis secara rutin dan juga rapat mingguan dengan karyawan yang membantu menjalankan usaha. Aspek human relation anatara entrepreneur dengan pemasok bahan baku dan pelanggan dijalan dengan cara pendekatan personal ahal ini dikarenakan karakter dari supplier ataupun konsumen berbeda-beda sehingga tidak mungkin menerapkan treatment yang sama dan digunakan pada saat menghadapi orang yang berbeda. Baite and Bite mengelola aspek human relation anatara anggota pemilik bisnis dengan membuat group dimedia sosial diamana setiap anggota dapat saling berdiskusi untuk kemajuan start-up bisnis yang dijalankan. Metode pada aspek human relation yang diterapkan kepada karyawan adalah dengan melakukan breafing setiap hari selama 10 menit sehingga karyawan akan siingatkan kembali dan sekaligus menyelesaikan konflik yang terjadi dihari sebelumnya.

\section{Analisis Peran Fakłor Eksternal Pada Keberlangsungan Start-Up Business}

Penelitian ini menggali informasi dari narasumber dengan menggali lebih dalam terkait bisnis yang dijalankan yang berhubngan juga dengan faktor eskternal bisnis diantaranya:barriers to entry in the industry, threat from substitute products, threat from suppliers bargaining power, threat from buyers bargaining power, dan rival among existing industry firms. Toko Lisanya menjelaskan jenis konsumennya adalah end user terdiri dari cafe, restoran, hotel dan konsumen dengan daya beli yang lebih besar daripada pembelian retail.Konsumen ini sangat loyal dan tidak mudah berpaling ke perusahaan lain yang menjal barang sejenis dengan toko Lisanya. Apek kompetitor, pemilik Toko Lisanya optimis bahwa bisnisnya aman dari kehadiran calon kompetitor karena informasi terkait supplier yang diamiliki disimpan dengan aman sehingga competitor sulit untuk mendapatkan informasi kunci terkait suppliernya.Barang pengganti dari produk yang dijual pada Toko Lisanya relative memberikan pengaruh yang kecil karena semua barang yang dijual oleh toko lisanya tidak banyak beredar dipasaran walau fungsinya mirip dengan barang yang ada di Toko Lisanya.Pengaruh supplier terhadap operasional/penyediaan barang di Toko Llsanya sangat kecil karena Toko Lisanya memiliki beberapa lapisan suplier yang cukup banyak sehingga tidak tergantung pada satu supplier tertentu.

Produk yang dihasilkan Kopi Kampoeng Arab menjal produk kopi yang memiliki campuran rempah asli Asia khususnya Indonesia. Perpaduan bahan bakudengan tujuan menunjukkan adanya perpaduan atau kombinasi budaya yang dirasakan saat menyeduh kopi Kampoeng Arab. Inovasi yang akan direalisasikan perusahaan adalah dengan menawarkan varian produk baru agar dapat menunjukan cita rasa budaya berkaitan dengan teh dan susu untuk menjaga cita rasa dan mempertahankan loyalitas konsumen. Tujuan dari Inovasi agar mampu bersaing dengan kopi lanang yang merupakan saingan utama Kopi Kampoeng Arab di area Kota Surabaya.Kopi Kampoeng Arab sangat optimis dan percaya diri menghadapi kehadiran pendatang baru/competitor hal ini karena sampai saat ini belum ada kopi di Indonesia yang menawarkan adanya akulturasi budaya Arab dan Indonesia.

Baite and Bite memproduksi cookiesyang dapat dijadikan snack sehat dengan bahan baku utama menggunakan oatmel. Alasan penggunaan oatmel karena mengandung banayak serat yang sehat untuk dikonsumsi serta aman bagi penderita kolestrol.Daerah pemasaran dari produk ini sudah mnyebar hingga Solo, Makasar, dan Surabaya.Peluang kompetitor masuk ke bisnis ini tidak terlalu mudah disebabkan karena perusahaan memiliki resep sendiri yang dibuat atas racikan dengan komposisi rahasia. Produk substitusi dapat kita jumpai di 


\section{Fransisca Desiana Pranata Sari Sri Nathasya Br Sitepu}

pasar yang memiliki fungsi relative sama dengan produk Baite and Bite cukup banyak namun sebagian besar merupakan produk impor dan belum banyak di Indonesia.

Samabal Kobonk menjual produk sambal dengan merek Kobonk pada kisaran harga Rp $25.000,00$ setiap botolnya.Daerah pemasaran produk ini tersebar di kota-kota yang ada di Indonesia hingga di luar negri walaupun dalam skala kecil. Keunggulan produk ini jika dibandingkan dengan produk lain adalah keamanan bagi kesehatan dikarenakantidak memakai bahan pengawet sehingga calon pesaing baru belum tentu dengan mudah menjadi pesaing produk ini. Sambal Kobonk memiliki harga yang cenderung stabil hal ini disebabkan karena teknik strategis yang diambil perusahaan melalui pengambilan batas atas harga cabe untuk mengantipipasi kenaikan harga. Inovasi dengan kemasan sachet menjadi nilai lebih lain yang menjadikan konsumen lebih memilih sambal Kobonk. Konsumen butuh kemasanyang sangat praktis. Pengaruh kebutuhan konsumen terhadap bisnis sambal Kobonk sangat besar sehingga ketika kebutuhan sudah terpenuhi maka konsumen menjadi semakin loyal terhadap perusahaan ini. Sambal Kobonk kurang terkenal jika dibandingkan dengankompetitor, namun perusahaan mengatasinya dengan cara melakukan inovasi dan promo sebagai keunggulan bersaing.

Mega Food merupakan bsisni yang uunggul dalam menajlankan bisnisnya karena produk yang dihasilkan menggunakan racikan sendiri sehingga calon pesaing yang ingin erebut pasar dari produk Mega Food ini sulit untuk bersaing secara langsung. Pengaruh pemasok bahan bahan baku ke perusahaan Mega food lemah karena bahan yang digunakan Mega Food dapat ditemui di semua pasar sehingga mega Food tidak terikat pada salah satu suplier. Ancaman dari produk substitusi cukup kuat namun Mega food berusaha mengatasinya dengan membuat berbagai macam variasi sambal mulai dari ayam, daging, dan tuna untuk memenuhi selera/kebutuhan dan kejenuhan konsumen terhadap salah satu varian rasa. Kompetitor seperti sambal Bu Rudy adalah kompetitor terberat Mega Food karena umur usaha Bu Rudy jauh lebih lama dari bisnis sambal Mega Food. Perancangan diatas mengambarkan situasi eksternal yang perlu dipahami oleh start up business terutama untuk bisnis dalam bidang makanan dan minuman kota Surabaya dalam rangka pencapaian keungguan kompetitif.

\section{KESIMPULAN}

Penelitian ini berhasil mendapatkan identifikasi awal mengenai faktor-faktor yang berperan dalam keberhasilan start up businesskota Surabaya. Peran yang dimaksud adalah dari faktor internal dan faktor eksternal. Kedua faktor ini sebaiknya perlu menjadi fokus utama perusahaan dalam mengembangkan bisnisnya supaya dapat bertahan dalam persaingan.

Dilihat dari faktor internal perusahaan, terdapat 4 kemampuan utama yang perlu dibangun seseorang dalam bisnis yang dirintisnya (Echdar, 2013:86) yaitu technical competence, marketing competence, marketing competence, dan human relation. Kompetensi teknis dilakukan sebuah organisasi bisnis terkait dengan rancangan usaha sampai kepada sistem yang dipakai. Kompetensi pemasaran diperlukan dalam rangka menemukan pasar yang cocok sehingga fokus kepada pelanggan dan demi menjaga kelangsungan hidup perusahaan. Kompetensi keuangan merupakan kompetensi yang penting pula karena perusahaan perlu mengatur seluruh keuangannya dengan baok terkait dengan pembelian, penjualan, pemukuan, sampai laporan keuangan untuk memberikan informasi mengenai kondisi perusahaan setiap bulannya. Kompetensi hubungan manusia dimana perusahaan perlu mengembangkan hubungan personal, berelasi dan membangun sebuah jaringan

Menurut Allen (1999) Faktor eksternal yang mempengaruhi sebuah start up business dapat bertahan dan bertumbuh adalah barriers to entry in the industry, threat from substitute products, threat from suppliers bargaining power, threat from buyers bargaining power, dan rival among existing industry firms.Barriers to entry in the industrymerupakan sebuah situasi 
dimana perusahaan dipaksa untuk melihat apakah hambatan masuk ke pasar yang sama dengan perusahaan itu mudah atau tidak, sehingga perusahaan dapat waspada dengan kemungkinan bertumbuhnya kompetitor. Threat from substitute products, yaitu produk lain apa yang dimiliki kompetitor yang fungsinya dapat menggantikan produk yang dimiliki perusahaan. Threat from suppliers bargaining power,yaitu perusahaan perlu menyadari posisinya dibandingkan dengan supplier apakah lebih kuat atau tidak sehingga aktivitas perusahaan tidak bergantung dengan ketersediaan bahan baku di satu suplier saja. Threat from buyers bargaining power, yaitu perusahaan perlu menyadari posisinya dibandingkan dengan pembeli apakah lebih kuat atau tidak sehigga perusahaan dapat memberikan aktivitas preventif apabila konsumen memiliki pengaruh besar dalam keberlangsungan hidup perusahaan. Rival among existing industry firmsmenjelaskan kondisi persaingan pasar dengan kompetitor saat ini.

\section{DAFTAR PUSTAKA}

Akan, Obasi, Richard S. Allen, Marilyn M. Helms, dan Samuel A. Spralls III, 2006, Critical tactics for implementing Porter's generic strategies",Journal of Business Strategy, Vol. 27 Iss 1 pp. $43-53$

Allen, Kathleen R 1999. Growing and Managing an Entrepreneurial Business. USA: Houghton Mifflin Company.

Blackburn, Robert A., Mark Hart, dan Thomas Wainwright 2013. Small business performance: business, strategy and owner-manager characteristics. Journal of Small Business and Enterprise Development. Vol. 20 No. 1, 2013pp. 8-27

Bungin, Burhan 2013. Metodologi Penelitian Sosial dan Ekonomi. Jakarta: Kencana Prenada Media Group.

Clancy, Laurence O' ConnellPaula, dan Chris van Egeraat, 1999, Business research as an educational problem-solving heuristic - the case of Porter's diamond", European Journal of Marketing, Vol. 33 Iss 7/8 pp. $736-745$

Cooper, Donald R dan Pameela S.Schinder. 2006. Metode Riset Bisnis.Jakarta:Grafindo.

Echdar, Saban 2013. Manajemen Entrepreneurship: Kiat Sukses Menjadi Wirausaha. Yogyakarta: Andi

Hendro. 2011. Dasar-Dasar Kewirausahaan. Jakarta: Penerbit Erlangga.

Pakroo, J.D. Peri H. 2014. The Small Business Start-Up Kit A Step-by-Step legal Guide. United States of America: Nolo.

Sugiyono. 2013. Metode Penelitian Bisnis. Bandung: Alfabeta

Susanto, A.B. et al. 2008. The Jakarta Consulting Group on Family Business. Jakarta: The Jakarta Consulting Group.

Temponi, Cecilia dan Wen Cui (2008). Factors impacting participation of Hispanic small businesses in government contracting in the USA. Journal of Small Business and Enterprise Development. Vol. 15 No. 3, 2008 pp. 504-526.

Umar Husein. 2005. Strategic Management in Action . Jakarta: PT. Gramedia Pustaka Utama.

Wang, W. and Chang, P. 2009, Entrepreneurship and strategy in China: why 'Porter's five forces' maynot be, Journal of Chinese Entrepreneurship, Vol. 1 No. 1, pp. 53-64, ISBN: 1756-1396.

Wickham Philip A. 2004. Strategic Entrepreneurship. England: Pearson Education Limited.

Wood, Emma H 2006. The internal predictors of business performance in small firms A logistic regression analysis. Journal of Small Business and Enterprise Development. Vol. 13 No. 3, 2006. pp. 441-453

Badan Pusat Statistik. 2016. PDRB Kota Surabaya Atas Dasar Harga berlaku (Data File). Sumber. www.bps.go.id Diakses tanggal 5 Juni 2016. 